\title{
Los viejos y nuevos arreglos de género en Sonora: la visión de los hombres Mesa de debate
}

\section{Felipe Mora Arellano}

Profesor de tiempo completo en el Departamento de Sociología y Administración Pública de la Universidad de Sonora.

\section{José Eduardo Calvario Parra}

Profesor-investigador Cátedra Conacyt en el Colegio Sonora.

\section{Ernesto Camou Healy}

Investigador en el Centro de Investigación en Alimentación y Desarrollo, A. C.

Los trabajos que se presentan en esta sección corresponden a la reflexión que compartió cada uno de los académicos convocados a participar en torno al tema: Viejos y nuevos arreglos de género en Sonora: la visión de los hombres.

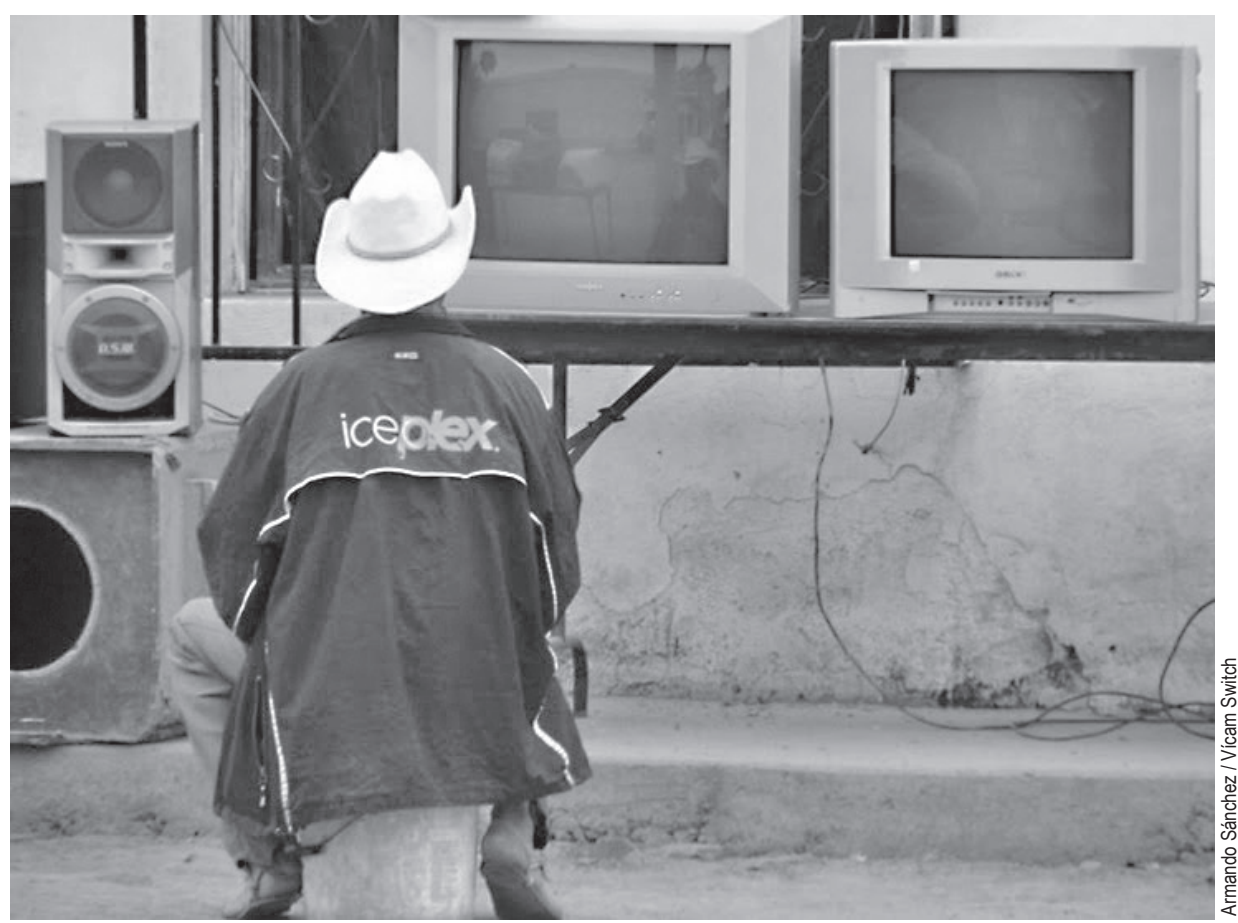

Viendo la tele. Literalmente, viendo la tele... (A. Valenzuela). 